\title{
MOOD System on Supporter Chant in English Premier League: A Systemic Functional Linguistic Study
}

\author{
Nur Rochman Fatoni ${ }^{1}$, Riyadi Santosa ${ }^{2}$, Djatmika $^{3}$ \\ \{1nrf.fatoni@student.uns.ac.id, ${ }^{2}$ riyadisantosa@staff.uns.ac.id, ${ }^{3}$ djatmika@staff.uns.ac.id\} \\ ${ }^{1}$ Graduate student of Department of Linguistics, Universitas Sebelas Maret \\ ${ }^{2,3}$ Lecturer of Department of Linguistics, Universitas Sebelas Maret
}

\begin{abstract}
One of the recent language phenomena in public area is supporter chant. Focusing on the interpersonal interaction among the participant, this research will examine the MOOD system with the SFL approach to determine the status and positions in chant discourse. This research is descriptive qualitative. The data is the clauses and words of the chant lyric downloaded from fanchant.com. It focused on the 'supporting' and 'mocking' player chant of the supporter of the Big Six clubs in English Premier League. The data is collecting through content analysis. The data is analysed through domain, taxonomy, componential and cultural theme analysis. From the MOOD system analysis, containing MOOD type, interaction function, and mood structure, the interpretation of both mocking and supporting chant put the singing supporter in an equal and balanced position with the listener. There is a special note on the mocking chant. Despite the structures place the players at different angles, their level of equality it still the same. Moreover, the message exchanged is in the form of information whether it is the players strengths, supporters hopes, promises, something happened, or a player's disgrace.
\end{abstract}

Keywords: chant, supporters, $M O O D$, status, interpersonal, $S F L$

\section{Introduction}

As time evolved in language and social life, the delivery of information is nowadays often manifested in the form of songs. It is often found in various fields not only in entertainment but in politics, education and even sports. It is interesting that singing or chanting becomes a tool for delivering messages in sports domain. Moreover supporters chant recently has been a worldwide trend beyond sports, especially football. The chant message can express a psichological feeling, social petition, support, and event a mockery to demoralize the the the opponent [1]. Supporter chant is originated from the creativity and fanaticism of Hooligans (supporters of football in England). It gives a fresh situation during a soccer match. Within the chant, the supporters can express a positive energy to support or even express mockery to football player as hatred's expression. Besides, the chant is also a song of identity for the supporters of a club and it becomes an entertainment in a football match.

As a language phenomenon, chant is a language system that [2] carrying messages or meaning from the speaker to the listener. Even though it is a one directional monologue 
having frequent repetition of words and only few verses, it offers a deep message to the listener. Those facts attract the researcher to examine the status or position of participants in the chant discourse. In functional linguistics, it belongs to the interpersonal meaning that investigating social relation including status, power or domination between participants. The status is related to relationships role or social status. According to[3] the purpose of social status or relationships role is how the social's roles played by participants, whether the position and status of participants are superior or equal.

The interpersonal meaning especially status, at the lexicogrammatical level, is realized by the MOOD system. [3], [4] explained that the MOOD system is a clause system conveying information exchange. It consists of indicative (declarative, interrogative) and imperative. The indicative clause in grammatical structure has the constituents of Subject (S) and Finite (F). Indicative declarative clause has a rule that the structure of the subject precedes the finite structure. In the indicative interrogative clause, the finite precedes the subject. In the imperative clause, there is no subject or finite, it only has predicator. [5] added the exchange of message in clauses is classified the interaction function into two, namely giving and asking [3], [5], [6]. The message can be a form of information and goods or services. The clauses containing giving information and asking for information is called a proposition. The ones giving goods or services and asking for goods or services is called a proposal.

There were several studies related to the MOOD system and status. In Mata Najwa [7], the MOOD system show that declarative clauses and proposition clauses convey the balance status of Najwa and the guests. Moreover, the proposal clause proved the dominations of Najwa Shihab to some guests. Another MOOD system research show the existence of indicative, declarative and interrogative clauses in male and female teacher talks in the EFL class. The analyses of the MOOD system of their utterances tells that the teachers act as a controller, director, tutor, and facilitator[8]. In another case, MOOD analysis examine the types of MOOD systems in the form of declarative, interrogative and imperative contained in the financial service tagline[9]. Then, the declarative and imperative MOOD types were found in the Lion Air' safety demonstration announcement [10]. In addition, in the MOOD analyses of the newsletter between general institutions and Islamic institutions [11], there are domination of declarative to carry information and also the use of imperatives functioned to orders and offers.

The outline of the studies above mentioned that several researchers examined the MOOD in various objects and developed MOOD analysis with context. The previous studies affirm the language phenomena that bring to the research gap. This research will explore the interpersonal status or position of participants by analyzing MOOD system. In addition, the domain is unique and special since still in a rare. The domain of the data is the supporter chant that then focused on the 'supporting' and 'mocking' players' chant of the supporter of the 6 biggest clubs in English Premier League called the Big Six. Through analyzing the supporting and mocking players chant will show whether there are different interpersonal status realised from those two types of chant. The supporters are only from the Big Six since the clubs are the biggest clubs in EPL that dominate the league in decades and also have a great supporter base. 


\section{Research Method}

This research is descriptive qualitative research using systemic functional linguistics approach focusing on the analysis of the MOOD system to see how the status or position of the participants. Furthermore, the data is obtained by content analysis techniques [12] with the technique of collecting archival records [13] through reading and note-taking. The data is in the form of words and clauses in the chants the lyric sung by the supporters at the stadium during the clubs' match. The researchers got the lyrics from the web providing the supporter chant lyrics, i.e. fanchant.com.

Then the data is analyzed using Spradley's [14] domain analysis, taxonomic analysis, componential analysis and also cultural theme's analysis. To separate the real data from the non-data[15], the chants is divided into two parts of domain. The domains are the mocking chant and the supporting chant from each of The Big Six. Then data is classified and analyzed with MOOD system as the taxonomic category. It is to organize the data on language phenomena using the theory of Systemic Functional Linguistic. The category of MOOD system contains clause types (declarative, interrogative, and imperative) as well as the interaction functions (propositions and proposals) [6]. In the componential table, the taxonomy categories are on the $\mathrm{Y}$ axis/ at the top of the table, while the domain is on the $\mathrm{X}$ axis/ on the left of the table. Then, their intersection will bring the research to the pattern of interaction, behaviour, and relations between the data and the categories that later point at the findings. Finally, in cultural theme analysis, the relationships pattern in componential analysis are interpreted with the context and the theory.

\section{Results And Discussion}

\subsection{Findings}

\subsubsection{Supporting Chant}

Table 01: MOOD System Realisation on the 'Supporting' Chant to Players

\begin{tabular}{ccccccc}
\hline Club & $\begin{array}{c}\text { Interaction Function } \\
\text { Propositio } \\
\text { n }\end{array}$ & Proposal & $\begin{array}{c}\text { Declarativ } \\
\text { e }\end{array}$ & $\begin{array}{c}\text { MOOD Type } \\
\text { Imperativ } \\
\text { e }\end{array}$ & $\begin{array}{c}\text { Interrogativ } \\
\text { e }\end{array}$ & $\begin{array}{c}\text { Minor } \\
\text { clause }\end{array}$ \\
\hline Man. City & 5 & 0 & 5 & 0 & 0 & 2 \\
Liverpool & 8 & 0 & 8 & 0 & 0 & 1 \\
Chelsea & 5 & 0 & 5 & 0 & 0 & 5 \\
Tottenham & 5 & 0 & 5 & 0 & 0 & 1 \\
Man. & 6 & 0 & 5 & 0 & 1 & 1 \\
United & & & & & & \\
Arsenal & 6 & 0 & 6 & 0 & 0 & 4 \\
$\Sigma$ & 35 & 0 & 34 & 0 & 1 & 14 \\
\hline
\end{tabular}

All of the clauses in supporting chant are 49 clauses. It contains more than 35 major clauses compared to 14 minor clauses. Here are the examples from the Manchester City chant:

Minor Clause : Ooooooo Balotelli, Mayor Clause : He's a striker, 
There is no proposal and imperative clause inside. All major clauses are propositions (providing information). Then it contains of 34 declarative clauses and only 1 interrogative clause. These are the examples of the MOOD system analysis in Liverpool club chant:

1.

\begin{tabular}{llll}
\hline If & he & scores & another few \\
\hline Conj & S & F / P & C \\
Re- & Mood & -sidue \\
\hline \multicolumn{4}{c}{ Indicative: declarative; proposition }
\end{tabular}

2.

\begin{tabular}{llll}
\hline then & I & 'll be & Muslim too \\
\hline Conj & S & F & C \\
Re- & Mood & -sidue \\
\hline \multicolumn{4}{c}{ Indicative: declarative; proposition }
\end{tabular}

The examples above are the proposition clauses with the indicative: declarative type. The next example will be indicative: interrogative from Manchester United club chant:

3.

\begin{tabular}{|c|c|}
\hline who & is he \\
\hline $\mathrm{Wh} / \mathrm{c}$ & $\mathrm{F}$ \\
\hline Residue & Mood \\
\hline
\end{tabular}

In mood structure, from the 35 proposition clauses, there are 22 clauses using personal subject pronouns to initiate the clauses ( $\mathrm{He}$ and I) and only 2 clauses using the name (see examples 4 and 5 from Chant Tottenham). Uniquely, in the supporting chant, there are 13 conjunctions used to initiate the clauses (see example 6 from Arsenal chant). In addition, all clauses are in positive polarity and there are only 3 modalities using 'will'.

4.

5.

\begin{tabular}{ccc}
\hline Eric Dier & loves & me \\
\hline $\mathrm{S}$ & $\mathrm{F} / \mathrm{P} \quad \mathrm{C}$ \\
Mood & Residue \\
\hline Indicative: declarative; proposition
\end{tabular}

\begin{tabular}{lccc}
\hline But & $\mathrm{He}$ & 'll be & Back \\
\hline conj & $\mathrm{S}$ & $\mathrm{F}$ & $\mathrm{C}$ \\
Re- & Mood & -sidue \\
\multicolumn{4}{l}{ Indicative: declarative; proposition }
\end{tabular}

\subsubsection{Mocking Chant}

All clauses of mocking chant in the data tabulation below are 52 clauses. It is more than the supporting chants. The clauses distribution of the mocking chant in the MOOD analysis is in the table afterwards:

Table 02: the Realisation of MOOD System on the 'Mocking' Chant to Players

\begin{tabular}{lcccccc}
\hline Club & $\begin{array}{c}\text { Interaction Function } \\
\text { Proposition }\end{array}$ & Proposal & Declarative & $\begin{array}{c}\text { MOOD Type } \\
\text { Imperative }\end{array}$ & Interrogative & $\begin{array}{c}\text { Minor } \\
\text { clause }\end{array}$ \\
\hline Man. City & 5 & 0 & 3 & 0 & 2 & 0 \\
Liverpool & 9 & 0 & 3 & 0 & 6 & 0 \\
Chelsea & 4 & 0 & 4 & 0 & 0 & 0 \\
Tottenham & 3 & 0 & 1 & 0 & 2 & 2 \\
Man. & 7 & 0 & 7 & 0 & 0 & 5 \\
United & & & & & & \\
\hline
\end{tabular}




\begin{tabular}{ccccccc}
\hline Club & $\begin{array}{c}\text { Interaction Function } \\
\text { Proposition }\end{array}$ & Proposal & Declarative & $\begin{array}{c}\text { MOOD Type } \\
\text { Imperative }\end{array}$ & Interrogative & $\begin{array}{c}\text { Minor } \\
\text { clause }\end{array}$ \\
\hline Arsenal & 14 & 0 & 14 & 0 & 0 & 3 \\
$\Sigma$ & 42 & 0 & 32 & 0 & 10 & 10 \\
\hline
\end{tabular}

There are 42 major clauses in the form of propositions out of all clauses. It is the different findings when the frequency of interrogative clause is higher than before. There are 32 indicative: declarative clauses and 10 indicative: interrogative clauses. In addition, there are also 10 minor clauses. These are the examples from Tottenham club chant:

\begin{tabular}{llll}
\hline Minor Clause : & $\begin{array}{l}\text { Heeeeeey hey Campbell } \\
\text { Wanker ... }\end{array}$ & Mayor Clause & Why you're such a cunt \\
\hline
\end{tabular}

In this part, the number of major clauses is greater than the one above while the number of minor clauses is less than the supporting chant. There are no proposals and imperative as well as the supporting chant. The lexicogrammatical structure shows 2 types of interrogative clauses. There are 4 clauses in wh- interrogatives and 6 forms of yes / no interrogative clauses. Uniquely, the 6 of yes/no interrogative clauses were only found in one chant, the Liverpool. The following is the example of MOOD System analysis in Man. United chant:

1.

\begin{tabular}{|c|c|c|}
\hline He & wears & a frock \\
\hline S & F / P & C \\
\hline \multicolumn{2}{|c|}{ Mood } & Residue \\
\hline
\end{tabular}

2.

\begin{tabular}{|c|c|c|}
\hline $\mathrm{He}$ & loves & the cock \\
\hline $\mathrm{S}$ & $\mathrm{F} / \mathrm{P}$ & $\mathrm{C}$ \\
\hline \multicolumn{2}{|c|}{ Mood } & Residue \\
\hline
\end{tabular}

Indicative: declarative; proposition

This is the example of wh- interrogative on Manchester City chant and yes/no interrogative on Liverpool chant with MOOD system analysis:

3. wh- interrogative

\begin{tabular}{|c|c|c|c|}
\hline Who & 's & [that] shagging & round Cardiff \\
\hline Wh / S & F & P & Adj. \\
\hline Re- & Mood & -sidue \\
\hline
\end{tabular}

4. Yes/no interrogative

\begin{tabular}{|c|c|c|c|c|}
\hline Have & you & ever & seen & Lampard [win the Euro] \\
\hline F & S & Adj. & P & C \\
\hline \multicolumn{2}{|c|}{ Mood } & \multicolumn{2}{c|}{ Residue } \\
\hline
\end{tabular}

The mood structure of the mocking chant is more variable. There are 14 clauses using subject personal pronoun 'You', 16 clauses begins with 'he/she', while others are 'it' and 'I'. There are also 'wh-question' and nickname 'the wife'. There are 3 vocatives and 1 continuative. In mocking chant, there is only 1 conjunction opens the clause.

5 .

\begin{tabular}{|c|c|c|}
\hline He & 's & half a boy \\
\hline S & F & C \\
\hline \multicolumn{2}{|c|}{ Mood } & Residue \\
\hline
\end{tabular}

6.

\begin{tabular}{|c|c|c|}
\hline You & 're & a cunt \\
\hline S & F & C \\
\hline & Mood & Residue \\
\hline
\end{tabular}


Cited from [6] and [16], the polarity is related to finite while the modality is the marker of speaker judgment. The grammatical structures of the mocking chants have no modality and negative polarity. In addition, the predicator lexis is dominated by negative lexis.

\subsection{Interpretation}

This section indeed belongs to the analysis of cultural themes. Findings from the componential analysis above is juxtaposed within the context and the underlying theory [15]. In general, the total amount of the 'supporting' and 'mocking' chants is 101clauses. They are 52 clauses of the mocking chant and 49 clauses of the supporting chants. The comparison is presented below:

Table 03: The Comparison of MOOD System Analysis in Mocking and Supporting Chant

\begin{tabular}{|c|c|c|c|c|c|c|}
\hline \multirow[t]{2}{*}{ Club } & \multicolumn{2}{|c|}{ Interaction Function } & \multicolumn{3}{|c|}{ MOOD Type } & \multirow{2}{*}{$\begin{array}{l}\text { Minor } \\
\text { clause }\end{array}$} \\
\hline & Proposition & Proposal & Declarative & Imperative & Interrogative & \\
\hline MOCKING & 42 & 0 & 32 & 0 & 10 & 10 \\
\hline$\%$ & $81 \%$ & $0 \%$ & $62 \%$ & $0 \%$ & $19 \%$ & $19 \%$ \\
\hline $\begin{array}{c}\text { SUPPORTIN } \\
\text { G }\end{array}$ & 35 & 0 & 34 & 0 & 1 & 14 \\
\hline$\%$ & $71 \%$ & $0 \%$ & $69 \%$ & $0 \%$ & $2 \%$ & $29 \%$ \\
\hline$\Sigma$ & 77 & 0 & 66 & 0 & 11 & 24 \\
\hline
\end{tabular}

In the componential table above, the clauses are dominated with the proposition clauses and zero proposal clause. In mocking chants, there are $81 \%$ of proposition clauses and the remaining $19 \%$ are minor clauses. In the supporting chant, there are $29 \%$ minor clauses and $71 \%$ major clauses are functioning propositions. The domination of the proposition clause implies that the chants exchange information [3]. Regarding the context, the information exchanged is about the players' pride or shame. Whereas the minor clause is dominated with the form of exclamations to shout out some nicknames for the players they addressee. This is intended to praise or even mock the players. Besides, other minor clauses are calls which functioned to clarify to whom the chant addressed.

The domination of the indicative: declarative proposition clauses, $62 \%$, in the mocking chant and $69 \%$ in the supporting chant is actually not only conveying information. However, it implies a judgment or opinion that pretended to be a fact. From underlying context, the fans bring their opinions and expectations to the players, as well as promises to do something if the players meet their expectations. Besides exposing the players to the listeners, these opinions and flattery are actually referred to motivate and boost the player's confidence. In the mocking chant, the supporters want to express their opinions related to the lack or disgrace of the addressed players.

The MOOD system of the clauses indicate the status or position of the participants in the interaction of exchanging messages[3], [4], [6], [16]. Chant is a supporter expression when watching football match in stadium. The language phenomena result on the three sides of participants, namely the singing supporters, the listeners, and the players. There were differences in the interactions status among them. The domination of the proposition implies that the supporters put themselves equal to the listener. The percentage of declarative clauses also means that the equality is present between them and the players the addressee.

The existence of interrogative clauses in mocking chant can be interpreted differently. In this chant, the interrogative clauses do not function purely asking for information. The interrogative clauses indeed function to involve the listener into the interaction, convey satire, 
and expose the players' disgrace. Basically, the grammatical structure of the indicative: interrogative proposition clause is still placing the supporters equal to the listener. However, the interrogative clause is a rhetorical question or does not need answers. The existence of the information inside the question itself in fact is intended to uncover the players' disgrace. It makes the addressed players is no longer positioned equally to the supporters.

In the mood structure, the subject is the source of negotiation in interpersonal interaction. Generally, initiating a clause with subject illustrates that the speaker still put themselves balanced or equal to others. A clause placing the player as the subject means that the players have no obligation to do something; unlike the proposal clause. In addition, the existence of positive polarity and a bit of modality shows evidence that supporters of the chant conveyed their hopes and opinions only [17].

\section{Conclusion}

The language phenomena on supporters' chant of English Premier League, especially at the Big Six clubs, presents two types of discourse meaning, mocking and supporting. The interpersonal interaction between the discourse participants, i.e. the singing supporters, the players, and the listeners is examined through the MOOD system with the SFL approach to determine the status and positions of them.

The analysis and interpretation of MOOD type, interaction function, and mood structure lead to the conclusion of the study. From the lexicogrammar in both mocking and supporting chant, the singing supporter puts himself in an equal and balanced position with the listener. There is a special note on the mocking chant. Despite its lexicogrammar place the players at different angles, their level of equality it still the same. Moreover, the message exchanged is in the form of information whether it is strengths, hopes, promises, something happened, or a player's disgrace.

Finally, the researcher is obliged to deliver the suggestion for further research. Chant discourse, whether in mocking, supporting, or other essence of the chant, still provides many aspects to be examined, of course, with the SFL approach. The lexicogrammatic element of the text provides the grammatical structure and lexical aspect as the research object. In this case, there is much lexis with unique character, generally rude in the mocking chant and excessive in the supporting chant. This will be interesting for other researchers to explore in further research.

\section{References}

[1] C. Rizza, "Semantically Redundant Language - A case Study," Appl. Linguist., vol. 30, no. 2, pp. 276-294, 2009

[2] M. A. . Halliday and R. Hasan, Language, Context, and Text: aspects of language in a socialsemiotic perspective. Oxford: Oxford University Press, 1985.

[3] R. Santosa, Semiotika Sosial: Pandangan terhadap Bahasa, 1st ed. Surabaya: Pustaka Eureka, 2003.

[4] Djatmika, Perilaku Bahasa Indonesia di dalam Teks Kontrak dari Kacamata Linguistik Sistemik Fungsional. Surakarta: UNS Press, 2012.

[5] T. Wiratno, Pengantar Ringkas Linguistik Sistemik Fungsional, 1st ed. Yogyakarta: Pustaka Pelajar, 2018. 
[6] M. A. K. Halliday and C. Matthiessen, Halliday's Introduction to Functional Grammar, Fourth Edi. New York: Routledge, 2014.

[7] S. Khaofia, Sumarlam, and Djatmika, "Mood Pada Talk Show Mata Najwa On Stage 'Semua Karena Ahok,"” in International Seminar on Language Maintenance and Shift (LAMAS) 7, 2017, pp. 661-667.

[8] Z. Fikri, "Mood Structure Analysis of Teacher Talk in EFL Classroom : a Discourse Study Based on Systemic Functional Linguistic Theory," GaneC Swara, vol. 9, no. 1, pp. 86-95, 2015.

[9] G. J. Putri and S. Mahdi, "Mood Analysis of Financial Services Taglines : a Systemic Functional Linguistic Approach," in UI PROCEEDINGS on Social and Humanities, 2018, vol. 2, no. C, pp. $1-4$.

[10] M. P. Wibowo and S. Mahdi, "Mood System of Lion Air ' s Safety Demonstration Announcement: A Systemic Functional Analysis," in UI PROCEEDINGS on Social and Humanities, 2018, vol. 2, pp. 15-18.

[11] D. Yuliana and E. D. A. Imperiani, "The Realization of Interpersonal Meaning in Course Newsletters: A Systemic Functional Linguistic Perspective,” Indones. J. Appl. Linguist., vol. 7, no. 1, pp. 181-188, 2017.

[12] C. Grbich, Qualitative Data Analysis. California: Sage Publications, 2007.

[13] R. K. Yin, A Case Study Research: Design and Methods. Bevery Hills: Sage Publications, 2009.

[14] J. P. Spradley, Participant Observation. New York: Holt, Rinehart and Winston, 1980.

[15] R. Santosa, Metode Penelitian Kualitatif Kebahasaan, 1st ed. Surakarta: UNS Press, 2017.

[16] L. Gerot and P. Wignel, Making Sense of Functional Grammar, 2nd ed. Cammeray, Sidney: Gerd Stabler, 1995.

[17] S.T. Widodo and K. Saddhono. "Petangan Tradition In Javanese Personal Naming Practice: An Ethnoliguistic Study." GEMA Online ${ }^{\circledR}$ J. of Lang. Stu. vol. 12 no. 4 pp 1165-1177, 2012 